\title{
Modern African Childhoods: Does Law Matter?
}

Julia Sloth-Nielsen ${ }^{1}$

\subsection{Introduction}

This paper poses a question often aimed at lawyers, especially when they straddle a culturally diverse and contested terrain of human experience, such as the role of children and families in society: does law matter? The question is all the more pertinent in African contexts, due to the pervasive poverty, prevalence of practices harmful to children, and perceived inability of weak states to put legislative intentions into effect.

The backdrop is the sociology of childhood, more particularly, childhood in African contexts. The paper commences in part 8.2 with a discussion of pre-modern African childhood. Thereafter, part 8.3 reviews the impact of colonial children's laws in constructions of childhood. It is argued that even the adoption of colonial children's legislation during the 2oth century failed to dislodge the primacy of culture in African childhood literature, and that by and large, formal law remained irrelevant to children's lives. ${ }^{2}$ Nevertheless, some legacies of colonial laws can be detected, and these are explained. The article then examines, in part 8.4, the implications of ratification of the UN Convention on the Rights of the Child (1989) (hereafter CRC) and the African Charter on the Rights and Welfare of the Child (1990) as far as the main question raised at the outset is concerned. In particular, the need for harmonization of domestic law with Convention and Charter principles is discussed, and the relevance of constitutionalism in modern Africa mentioned. The final part of this section examines the setting of an upper age of childhood, other age-related issues fundamental to modern African childhoods, marriage and gender equality, child participation, access to education, HIV/Aids as a driver of childhood constructs and socio-legal change, and harmful cultural practices. Part 8.5 contains a conclusion. It will be proposed that the introduction of a child rights discourse via the CRC and the African Charter on the Rights and Welfare of the Child, coupled with the implementation of large scale continental law reforms, has altered not only the legal landscape, but so too the present day understanding of childhood at a much more fundamental level. The conclusion that this paper puts forward is that law does matter: and that an irreversible journey has been set in place which redefines African childhood.

\footnotetext{
${ }^{1}$ Dean, Faculty of Law, University of the Western Cape, South Africa.
} 


\subsection{Pre-modern African childhood}

Several propositions can be put forward to characterize childhood in African contexts (the word contexts is used here as no single or unified conception can purport to represent the universal experience of childhood in Africa). ${ }^{3}$ But for some authors, there was in fact no concept of childhood, as commonly understood, in traditional African culture. 4 This view is contested: it belies the protections accorded children within the family by other means. For instance, it is well known that children's voices were heard through older relatives such as grandmothers whose role was to protect the children's interests thereby allowing for less formal and more interactive relationships between grandparents and their grandchildren.

The period during which a person was presumed in traditional African society to be a child was a diffuse one: on the one hand, children were expected to assume responsibilities towards the household from an early age. These could include adult-type responsibilities, such as child rearing in relation to younger siblings, tending crops and livestock, fetching water and, in an overall sense, contributing in essential ways to the means of production and reproduction.5 In this sense, 'childhood', as known in the western world today, was not a protected period of physical and psycho-social development in African societies. Rather it was a time-limited period of consummate dependency, followed by a gradual and inexorable progression into adult life: this progression commenced almost immediately a child could function independently.

Further, African childhood was generally marked by constant changes in status, roles and responsibilities, rather than having a single exit point at a defined age. ${ }^{6}$ The actual legal transition into a senior societal role was a functional outcome of various and different occurrences, procedures or events. Establishing a hearth could be one, circumcision another, or taking a wife a third: the context and the cultural vehicle for transformation to adult status differed across cultures and tribes. This transition would have been neither automatic nor universal: in many instances, the perpetual minority status of women ensured that they never really migrated from childhood into adulthood; second or subsequent (male) siblings might have been similarly awarded lesser adult status, whatever their age, in view of the customary rules of primogeniture; and even widows, freed from the strictures of husband-rule, would frequently be subject to ancillary customary laws and traditions which preserved minority status through leverite practices, widow cleansing and suchlike. ${ }^{7}$

As in other cultures, the onset of puberty played an important role in child/adult transitions: a girl (especially) who had reached puberty was regarded as being of marriageable age. This link between puberty and adulthood affected not only the exit from childhood, but a range of other related themes, such as child marriage, child labour and the rights of the child in and to education. ${ }^{8}$ 
Child protection, as a formal response to the abuse of the child within the family was an unknown societal phenomenon. This was likely because child rearing was a family concern, which did not involve the state or other institutions of governance. Instead the protection of children from excessively harsh treatment was a duty of other family members acting in a guardianship role towards children of the kinship circle or clan.

The harsh treatment of children was fairly commonplace, prevalent in practices which in places ranged from debt bondage of children to trafficking and sale of children. It is argued, though, that it is factually incorrect to depict the lack of attention to child protection as equivalent to the wholesale treatment of children as chattels or property in the family context: rather, children were cherished and valued, as semi-productive contributors of the future for the kinship unit.

There are many sayings, in cultures throughout Africa, which point to the value of children in family life, and it is crudely reductionist to equate this 'value' to monetary or fiscal terms. ${ }^{9}$ Rather, 'value' in this sense bears a wide meaning: it entails that children are a form of emotional 'wealth' far beyond their present or potential economic contribution. Illustrative of the 'value' of children to the kinship group are the range of practices in customary law designed to enhance the child bearing and child rearing functionalism of the kinship group, such as leverite and sororite practices, women-to-women marriages and so forth. From this, it can be deduced that children qua children were indeed beneficiaries of a customary conception of childhood, albeit that this differed from western versions.

Pre-colonial and to a significant extent even colonial Africa was a rural society, functioning with a pre-industrial subsistence economy, and with children as part and parcel of the means of production. Aries, Prout and James and others have linked the emergence of childhood to the industrial revolution in western society, and law has been shown to be a critical adjunct to this process. Commencing with the emergence of laws restricting child labour, ${ }^{10}$ the founding of the welfare system and the antecedents of the juvenile court, ${ }^{11}$ the vision of childhood as an era of protective concern is a post-industrial period development. In Africa, however, the historical trajectory of the development of child laws and a child rights discourse has been somewhat different to that in the north.

\subsection{Colonization, children and the law before 1990}

It is somewhat unrealistic to assume that there might have been a leap from pre-colonial society to modern child rights-based legal systems without any intervening occurrences. In most African countries, as former colonies, legislation was adopted in the course of the 2oth century to create some kind of ad hoc legal framework relevant to juveniles or children. The review of legislation that preceded the adoption of the Kenyan Children's Act 2001 revealed the existence of more than 61 statutes affecting children, which the new law consolidated and modernized. ${ }^{11}$ The 
Children's Act 38 of 2005 of South Africa repealed at least six discrete statutes dealing with children's status and welfare. The Law of the Child of Tanzania of 2009 repealed a number of previous enactments, and the Child Rights Act of Nigeria of 2003, in a similar vein, followed the Children and Young Persons Act of 1943, which was revised in 1958. This law related mostly to juvenile justice administration, and defined a child as a young person under the age of 14 years. The Namibia draft Child Care and Protection Act, 2010, will repeal such enactments as 'The Children's Amendment Act (Rehoboth) 1981', and parts of a law called the 'Commonwealth Relations Act, 1962'. It will fundamentally, replace the Children's Act of 1960, imported from South Africa before independence in 1990. The Lesotho (Child Welfare and Protection) Act finalized in 2011 has abrogated the colonial law which forbad the adoption of Basotho children by their own citizens of the country, privileging adoption for Europeans (sic) only. ${ }^{13}$ Malawian colonial legislation has been very much in the public domain, thanks to the well publicized 'Madonna' series of cases. ${ }^{14}$ The adoption law at stake in these cases dates to $1951 .{ }^{15}$ Its enactment must be seen against the background that adoption as a customary law concept was for many peoples not only entirely unknown, but indeed contrary to basic tenets of ancestor and clan linkages, which are crucial to customary affiliation laws in many parts of the continent. ${ }^{16}$ A number of countries appear to have enacted child protection laws in the 1970s, largely focused on juveniles in conflict with the laws. Examples include Zanzibar, Mozambique, Botswana and Lesotho. These were at best partially implemented. By way of example, the 1971 Juvenile Code of Mozambique, enacted shortly before Portuguese exit from the country in 1975 was a model 'non-African' example: referring to non-existent structures and responsibilities, to be performed by non-existent functionaries. ${ }^{17}$

It can be concluded that African child law history demonstrates a pattern of the assimilation of law which mirrors some developments in the 'mother countries' and provides concrete evidence of colonial influence. Moreover, the institutions of the colonial era have found a place in many African countries, not just in law, but also in practice: borstals, approved schools, reformatories, schools of industry and re-education facilities are (and were) part of the half hearted attempts 18 to create separate institutions for children to underscore child welfare and juvenile justice systems. Some colonial laws were racist in their content, others became so via their application. The de jure discrimination against nationals in the field of adoption in Lesotho has been noted. In South Africa, the child maintenance grant, a form of child support, was payable in practice only to white and mixed race persons until it was comprehensively overhauled in 1997 and replaced with a single child support grant payable to any primary caregiver of children who qualified on the means test. Zaal has written eloquently on the ways in which the apparently neutral children's court apparatus was used to promote apartheid ideology, and further race classification for the purposes of racial segregation. ${ }^{19}$ 
Many colonial era child laws fell far short of a child rights orientation at even the most basic of levels: provisions for the reporting of child abuse did not feature at all, and the ideology of the delinquent, vagrant, promiscuous child (or child exposed to sexual exploitation) pervaded concepts of which children were in need of protection or care. State care systems, as such, were non-functional, and the 'duty' to provide child protection services rested mainly on civil society and religious organizations. Such juvenile justice statutory provisions as did exist were frequently encapsulated in isolated provisions of penal and criminal procedure codes. South Africa's position until 1 April 2010, when a dedicated Child Justice Act (75 of 2008) came into force, illustrates this point (Nigeria, Rwanda and Ethiopia constitute three further examples). Fragmentation of statutes affecting children was evident in other areas as well, such as affiliation laws, inheritance laws and laws relating to the maintenance of deserted wives and children.

Nevertheless, the existence of legislation relating to children before the CRC and African Charter did set in place the following legacies:

1) They created, in some places, the expectations of a discrete philosophy of childhood articulated through the creation of some separate institutions, through affiliation and family codes, through isolated provisions of criminal codes and procedural laws which contained some concession to youth or immaturity, ${ }^{20}$ and through the introduction of western law concepts such as contractual and other status-bearing events such as the attainment of majority upon conclusion of a civil marriage. How deep this ran differed from place to place. South African and other Roman Dutch territories (Zimbabwe, Namibia, Botswana, Swaziland) as well as Uganda, Kenya, Tanzania and Malawi, had an elaborate system of personal law by the time of the introduction of the CRC, based on a century of indigenous judicial precedent as well as the old statutes. Many texts on 'The Law of Persons', dating back to the 1900 s, testify to this.

2) Second, some conception of separation of childhood from adult status did take root. There is no better testimony to this than the early declarations on children of the Organization for African Unity (OAU) (now the African Union (AU)), which predate the CRC and the international child rights movement to some extent. ${ }^{21}$

3) Third, a welfarist leaning was readily discernible, and a conflation of delinquency, danger and disgrace were manifest. As recently as a decade ago, this was shown to prevail in studies analyzing children's court proceedings in Kenya, where the majority of children appearing were street children, vagabonds and urchins. This was possibly because of an underlying premise that welfare was the preserve of the African (extended) family. State intervention would occur only when public order was at stake, visibly so in the case of street children.

South African trajectories were slightly different: the 'swart gevaar' (black danger) relegated children in any sort of trouble to the penal system, where they were disallowed the 'benefits' of the welfare system. It is no surprise that, at the dawn of 
democracy in 1996, children's welfare institutions were largely segregated by race, and mostly reserved for white and mixed race children-black children were rarely brought within the purview of the formal welfare system in South Africa for most of the previous century. ${ }^{22}$

4) Finally, the existence of the legislation for the welfare of children that prevailed did imply, in theory, a state system which could intervene to protect children where this was deemed necessary. But the idea of the 'least detrimental alternative' or 'minimum intervention' did not feature in law. Also, the indigenous systems of child protection, restorative justice and community-based dispute resolution did not rise to the surface at all. It is only in the recent raft of child protection statutes that some attempt has been made to capture indigenous concept and practices, a fuller discussion of which lies beyond the scope of this article. ${ }^{23}$

\subsection{Implications of the CRC (1989) and the African Charter on the Rights and Welfare of the Child (1990)}

African countries were amongst the first to ratify the $\mathrm{CRC}^{24}$. At the time of writing, 45 states (of the 53 member states of the African Union) are signatories to the regional treaty, the African Children's Charter.

The CRC requires a macro-level re-orientation of the relationship between state, family and child, with a newly established role and set of responsibilities for the state in relation to the Anne McGillivray, Labyrinth October 2010 Law and Childhood Studies construction of childhood and its socio-political organization. ${ }^{25}$ State parties undertake upon themselves a defined role in relation to the promotion, protection and fulfillment of the rights of children, and thereby also irretrievably impact on and

alter the rights of the family. ${ }^{26}$ Thus, while articles 5 and 18 recognize the primacy of the role played by families in child rearing, a subsidiary role for states to support them in these endeavours is carved out. Article 19 crucially accords states a front line position in the protection of children within the family, and commits ratifying states parties to a range of actions and interventions to protect children, irrespective of in whose care they find themselves. This underlying orientation, which views childhood as a matter of public, and not merely private concern, is especially relevant for modern African childhoods.

Second, fulfillment of international obligations incurred by ratification is principally achieved through the reporting mechanism set up in the body of the treaty itself. Reporting brings with it the prospect of bringing the largely 
hidden-from-scrutiny-arena of child rearing into the public domain, at least on the international plane. ${ }^{27}$ Hence, matters which relate to areas as varied as health, sexual exploitation and cultural practices have increasingly been documented and placed under the spotlight of the international community through the reporting process, and cannot be shielded behind domestic particularity or local tradition. Female genital cutting is the most widely known example, but there are others: ukuthwala (seduction amongst the Xhosa), trokosi (sexual slavery in Ghana), targeting of children as witches (Burundi), 28 and killing of albino children (Tanzania). Largely since the adoption of the CRC, these and other issues have emerged from being merely anthropologically interesting to become legally significant. ${ }^{2} 9$

Third, and following on the above, it is clear that ratification brings with it domestic responsibilities: the municipal dimension. Thus CRC's article 4 requires states parties to undertake 'all appropriate legislative, administrative and other measures for the implementation of the rights recognized in the Convention. . . . ' Harmonization of domestic law with international principles is therefore required, and it is thus that almost all countries in southern and eastern Africa, Northern Africa, and many in Central and West Africa have undertaken legislative reviews and have updated and remodelled their children's laws, this time with a principled and comprehensive treaty as guidance. In fact, two early starters, Uganda (1996) and Kenya (2001), are amidst the second wave of reform. ${ }^{30}$

The colonial enactments of the previous century are being replaced and expanded to produce a new set of principles and practices which define childhood, the state and the family. Some of these are addressed in more detail shortly. A central question that arises for consideration is whether the project of domestication in turn impacts upon understandings of childhood at a micro level, or societally, generally; this is an issue to which I return in conclusion.

The development and formulation of the African Children's Charter in 1990 (in effect from 1999) is a relevant additional factor in answering the central question posed in this article. The Charter was advocated as a regional response to the development of a child rights discourse at the international level. ${ }^{31}$ African countries, having played a rather marginal role in the overall framing of the $\mathrm{CRC}^{32}$, were persuaded that a regional children's rights treaty would be apposite not only to address the evident gaps and socio-political absence of African concerns from the dominant agenda, but also to reinforce the notion that an African conception of children's rights did exist. The concerns to which the African Children's Charter speaks include the use of child soldiers, children of imprisoned mothers, a culturally specific understanding of the concept and role of the extended family in matters of child care, the (then) plight of children living under apartheid, gender inequality in relation to female children and harmful practices, the position of refugee and displaced children and the definition of the child. It has been asserted that adoption of the ACRWC was not simply evidence 
of an African rush to echo precepts already contained in the CRC, but rather substantiation of an abiding concern for children and protection of their rights within the OAU (now the AU). ${ }^{33}$ The Charter followed a previous Declaration on the Rights of the Child as well as considerable activity at regional level on issues prevalent in children's rights discourse, especially on child health and child labour. The ACRWC too embodies an obligation to provide for its principles in domestic law.

Children's rights were thus not alien to Africa, or imposed, nor were they simply adopted and adapted from the north. Instead, they were alleged to have a strong local resonance, most aptly encapsulated in the preamble to the Charter and in article 31, setting out the duties of the African child. 34

Treaties themselves are, of course, a form of law. Therefore, at a very simplistic level, the fact of ratification by states parties in Africa of both the international and the regional documents implies that there is strong support for the conclusion that 'law' does matter insofar as state obligations to a particular conception of childhood have been formally underwritten. This high level impact is bolstered by recognition of children as constitutional subjects: a majority of African constitutions refer explicitly to a variety of children's rights, ranging from education rights to protection rights. ${ }^{35}$ South Africa takes a lead position internationally in constitutionalizing justiciable children's rights, which have, since the adoption of the 1996 constitution, resulted in a wealth of jurisprudence giving effect to a thoroughly modern conception of childhood rooted in human rights law and based on modern philosophies, such as child participation.

\subsubsection{The upper age}

The CRC, and the ACRWC unequivocally, set the age of childhood as extending to the age of 18 years. It has often been noted that the ACRWC affords higher protection than the CRC, as it does not permit of exceptions where national law provides for a lower age of majority, as does the CRC. Another obvious age-related issue concerns the minimum age of marriage, which the ACRWC establishes as a legal norm to be 18 years.

The de facto earlier entry into adulthood for African children which has prevailed has given way to a plethora of legal provisions which enshrine 18 as the age until which the protection of the status of childhood will endure. Colonial laws were uneven and insecure about defining childhood at all. In South Africa and some neighbouring states, the age of majority was set at 21 years, a position which changed in South Africa only in 2007, and which in Namibia will only change with the adoption of the Child Care and Protection Bill 2011. Previous legislation which set an age at below 18 has been revised upwards in some places (e.g. Mozambique). 
It can be concluded that as regards the new provisions on age, law does matter: 18 has been established uncontroversially in many constitutions and domestic laws in accordance with the international treaty provisions, and customary conceptions have had to recede. The minimum age for extending protection against trafficking has been similarly set at 18 years (e.g. in Law of Benin $n^{\circ}$ 2006-04 of 10 April 2006; Chapter 17 of the Children's Act 28 of 2005 of South Africa).

\subsubsection{Some other age-related concerns fundamental to the adult/child dichotomy in Africa}

Culturally relevant events which raise flags in the discussion about whether law matters to African childhoods include marriage, especially child marriage, and the age of sexual consent. The fact of public outrage in Nigeria over the marriage of a 50-year-old senator to an Egyptian minor of 13 years in 2010 lends some credence to the contention that customary and religious conceptions of marriageability at puberty are receding. The 2003 Child Rights Act of Nigeria clearly provides for 18 years as the legal age for a valid marriage and the corresponding Egyptian law also prohibits child marriage. It is increasingly untenable to defend child marriages as excused by religious rights or the right to privacy, in the face of nationally and internationally binding agreements. The contention is that insofar as custom is being abrogated, law does matter. 36

The legal framework within which marriage of girls must be considered includes the Convention on the Elimination of Discrimination Against Women (CEDAW) and the African Women's Protocol (in force from 2007). Both take equality within marriage and freedom of choice (i.e. voluntary entry into marriage) as axiomatic, and enjoin states parties to ensure this through legislation.

But the colonial heritage of many states is legislation providing for different ages for the minimum age of consent to sexual intercourse for girls and boys. Frequently, the age for girls is lower, and is allegedly linked to their earlier physical maturation. Sexual consent laws are both contentious and confusing. South Africa's recent attempts to achieve a uniform minimum age for consent (at 16 years, below which sexual acts with a child constitute a statutory offence), 37 yet provide protection from exploitation, have led to the adoption of controversial provisions which criminalize consensual sexual acts between teenagers, which in turn raises the issue of children's autonomy and self-determination rights. ${ }^{38}$ There is little unanimity regarding the ages of consent to sexual entree in African legal systems, although where protective provisions relevant to HIV/Aids are concerned, the tendency is to permit voluntary testing for HIV at an age well below 18 years which indicates a certain degree of schizophrenia about when children should be recognized as sexual beings. 39

Summarizing the relevance of age to understandings of childhood in modern African systems, it is argued that there has been an inexorable movement towards agreeing 
that childhood up until 18 is a period of immaturity warranting differential treatment. This has occurred notwithstanding a cultural view that children still have responsibilities towards their families and duties to contribute to the maintenance of the family's means of production. Protection is also evident in the setting of a minimum age of marriage at 18 years in many new children's laws, and a more protective (legal) stance towards the age of sexual debut.

\subsubsection{Non-discrimination}

International law requires that legislative attention be paid to outlawing any form of discrimination against children on a variety of listed grounds, such as legitimacy, gender and race. However, attempts to address equality in marriage laws that have been enacted in recent times in some African states have been controversial, the controversy extending to the position of extramarital children.

Namibia adopted, after intense Parliamentary debates, legislation concerning child custody which provides for unmarried women and men equally to be appointed custodian of a child born out of wedlock, but only the one of them: the one de facto raising the child. $4^{0}$ Payment of child support is also- gender neutral (on paper), as the custodian parent is primarily responsible for the rearing of the child and the payment of all expenses. But apparent gender neutrality in attempts to give effect to the equality provisions of international and regional treaties can mask and even entrench traditional gender inequality, since it is most often mothers who raise children born out of wedlock.

Kenya's Children Act 2001 has become renowned for the lassitude granted errant fathers of children born out of wedlock to escape responsibility for their offspring. Numerous judgments have confirmed that the father must acknowledge paternity before acquiring rights, and that the duty to support a child does not arise before that event. ${ }^{41}$ The $2010{ }^{\wedge}$ constitution of Kenya, which clarifies the responsibility of both parents to provide child support, will require a revision of the Children Act's scheme.

In South Africa, the Children's Act 37 of 2005 does not give full and completely equal recognition to biological fathers who were or are not married to the mother at or around the time of the child's birth. Section 21 of the Act provides a scheme whereby, provided the biological father satisfies certain predetermined criteria (some of which are objectively ascertainable, such as whether he was living with the mother at the time of the child's birth, and others of which are more amendable to interpretation-such as whether he has made a 'reasonable contribution' to the expenses and to the upbringing of the child') in order to vest him with parental rights automatically. 42

The abovementioned recent statutes addressing the position of unmarried fathers, and of gender equality outside of marriage, are bound up in the requirements of the 
CRC and ACRWC to ensure that children do not suffer discrimination on account of the marital status of their parents. The new children's laws giving effect to this on the continent alter customary affiliation rules and will ensure a greater obligation on unmarried fathers to provide material support to their offspring.

\subsubsection{Child participation}

Both the CRC and the ACRWC are unique in according children the right to participate in matters affecting then, and requiring their expressed views to be given due weight. This principle runs quite contrary to traditional conceptions of children in African contexts, grounded in children's respect for elders, which presupposes a hierarchical societal structure in which children are regarded as having insufficient societal status to express useful opinions or views.

In modern Africa, the concept of child participation is being given effect to in various forms. This development is undoubtedly inspired by the processes of domestication of the CRC and ACRWC. Prominent examples include the establishment of children's parliaments, 43 the consultations with children held at the time of the UN Violence study, and in-country developments regarding legal representation of children charged with offences. 44

This new continental focus on hearing children's voices spreads far and wide. Concerning Niger, arguably amongst the most traditionalist (and Islamic) of African societies, it has been said that:

The institutional organ, the youth parliament, is that it constitutes an environment of expression, concentration and permanent exchange which allows the children to call out to the public authorities and their parents on the matters of these times: violence in the family and school environment where they are the victims or authors. Based on this, they participate actively [in] the public and political life of the country and thus become full actors in the elaboration and reforms of the laws. Another advantage of this youth parliament is that it weakens the prevailing seniority principle which ensures that the young keeps quiet and obeys to the elders. 45

Consultation about law reform with children is a fairly advanced endeavour, having commenced with consultations in the 1990s in South Africa at the time of drafting of the Child Justice Act and the Children's Act. The Mozambique legislation of 2008 was also preceded by a dedicated process of consultation with specific groups of vulnerable children (victims of child labour, or sexual exploitation and child prostitution, children in conflict with the law and so forth).46 The recent development of the Namibian Child Care and Protection Bill of 2011 was furthered by innovative and multipronged methods of reaching children, including through class room debates on certain key themes in the Bill, through 
newspaper inserts in several languages at periodic intervals, through a 'sms' campaign which saw children responding to questions such as 'what the minimum age of majority should be' and at what age the law should permit consent to medical treatment, followed with the establishment of a 'facebook' group for children and young people to discuss law reform questions. 47 This was supplemented by face-to-face consultations with groups in remote rural areas. The present process to develop a new children's law for the island territory of Zanzibar has been accompanied by probably one of the most extensive child participation exercises yet to take place, with village and district level child groups, formally constituted, debating child protection, child labour, responses to juvenile delinquency, and other intended aspects of the proposed new statute. Each and every district in the twin islands of Ungugaa and Pemba has been included in the consultation exercise.

Children's radio, hotlines for children and access to justice initiatives flesh out the array of child participation strategies that have been identified. Celebrations of the Day of the African Child (an initiative launched by the African Committee of Experts on the Rights and Welfare of the Child, held annually on 16th June) typically involve children's participation in the exercise of their rights in a variety of media and via many models (drama, radio, debates, competitions, schools-based activities and so on). In South Africa, March 2011 saw the completion of the first national schools human rights moot competition, the final rounds of which saw children debating at the Constitutional Court.

NGOs, civil society organizations and of course the international donor community are undoubtedly driving these developments. As a consequence, it may be contended that child participation is not organic, culturally approved, or a widespread and grassroots counter to the traditional invisibility of children in Africa. However, it may be suggested that even if child participation is occurring only to a fairly limited degree, the growing acceptance of hearing children's voices is worthy of note, insofar as traditional conceptions of the role of the child have had to shift to accommodate these new forms of child participation.

\subsubsection{Access to education}

Arlene Skolnick writes that '[t]he institution of schooling in Western societies has had profound effects on conceptions of childhood as well as on children themselves. It is school, along with the family, that defines the child's place in contemporary Western culture. For us school is the "natural habitat" of childhood, the school child is the child. The concept of childhood, the emergence of the private, emotionally intense family, and the idea of the school as part of the "normal" socialization of the child were different aspects of the historical process of modernization.'48 
The CRC and the African Children's Charter enshrine the child's right to basic education without qualification. For Africa, the drive to spread access to education has assumed a new dynamic since the identification of universal primary education as one of the Millennium Development Goals. The effects have been dramatic, albeit that the goal of universal primary education for all will not be met by 2015. In many countries, enrolment rates have escalated sharply affecting both boys and girls. Comparing village life and town life in modern Uganda, Cheney explains the local effects of the drive towards education on childhood in Africa, and the way in which education severs the rural link and constructs a new African childhood. 49 This result is surely multiplied across the continent, where more and more children are now in school.50 Implementation of the right to compulsory education brings with it a new experience of childhood for the African child of today.

\subsubsection{HIV/Aids as a driver of understandings of childhood and concomitant legal changes}

The impact of HIV upon children in Africa has been well documented and its impact felt upon policy and law reform initiatives since the mid 1990s. First, it has had a bearing on issues relating to consent to treatment and to HIV testing, where states have had to take account not just of children's evolving capacity to provide such consent in abstracto, as it were, but also on account of the potential lack of availability of parents and guardians able to furnish substitute consent due to the growing numbers of children orphaned by the disease. South Africa's Children's Act 38 of 2005 provides an example, as it provides for a new minimum age of consent to medical treatment (12 years, provided that child understands the nature and import of the treatment concerned: section 129), and a minimum age for consent to HIV testing (again 12 years, but without the proviso concerning sufficient understanding or maturity, and further providing that a child below the age of 12 years can furnish consent to a HIV test if such child is sufficiently mature to understand 'the benefits, risks and social implications of the test': section 130). Children will be considered mature if they can 'demonstrate that they understand the information on HIV Testing and can act in accordance with that appreciation.... ' taking into account the child's age, knowledge of HIV and its implications, views, and personal circumstances..$^{51} \mathrm{~A}$ third highly contested provision ${ }^{52}$ concerns access to contraceptives: section 134 of the Children's Act states that no person may refuse to sell condoms to a child over the age of 12 years or to provide these on request where they are available free of charge. Contraceptives other than condoms may be provided on request by a child, without parental consent or knowledge, if the child is aged 12 or older and the child is given proper medical advice and an examination to determine whether there are any medical contraindications to the provisions of a specific contraceptive. These provisions prompted concerns for children's reproductive health and policies that privilege the protection of children over cultural objections or opposition from parents. The HIV-related legislation illustrates the point that children's agency and evolving capacity is fundamentally altering the construction of childhood. 53 
The second arena where HIV/Aids has played a role in bringing modern African childhoods to the fore is in relation to alternative care. It has been noted that the pandemic has, in fact, spawned a new language in child rights policy circles54: of child headed households, OVCs (orphaned and vulnerable children), and kinship care, all slowly wending their way into policy and legal instruments. The impact of HIV/Aids on the breakdown of the extended family, burgeoning numbers in orphanages and children without parental care, has brought the issue of the traditional care of African children within family and clan structures to the surface, as numerous studies have shown the lack of coping ability of families devastated by HIV/Aids (even if the orphan estimates of the late 1990 s and early 2000 s have not played out to the extent that some have predicted). Consequently, much current NGO and civil society work, not to mention policy initiatives and donor support is geared towards shoring up community structures to enable the 'traditional family', often comprising only the older generation, with the middle generation having themselves been decimated by the ravages of the disease, to perform the care function that states are unable to do.

HIV/Aids has revealed, if nothing else, that the image of an idyllic rural childhood spent secure in a tight knit family circle surrounded by a clan of diverse caregivers is, for many vulnerable children, a myth. Fieldwork over the last decade has pointed to children's extreme vulnerability to exploitation and deprivation of both basic and other (e.g. psycho-social) needs, and the inability of traditional family and kinship structures to step into the breach due to the HIV pandemic. Legal responses to the orphan crises are legion, ranging from formal recognition in civil law of kinship care arrangements (Namibia, South Africa, Tanzania), to new regulations governing the establishment and functioning of alternative care institutions (Kenya).

\subsubsection{Harmful cultural practices}

Anecdotally, it is evident that the most objectionable harmful cultural practices which violate children's rights are in retreat. Thus, the full story of the extent to which female genital mutilation (FGM) is receding at grass roots level is one that needs to find expression: too many narratives focus on the practice as if the fact that it continues to occur indicates the impossibility of furthering children's rights in African context, and seem to point to the futility of legislative reform to prohibit and criminalize the practice.55 Egypt's report to the African Committee of Experts on the Rights and Welfare of the Child (ACERWC) is a benchmark in providing evidence of a steep decline in the practice, as the government has used village level approaches to combat and prevent FGM as an adjunct to formal law and policy. ${ }^{6}$ Anecdotal reports suggest that in countries such as Ethiopia, programmes targeting village women are having similar effects. 


\subsection{Conclusion: laws do matter?}

The conclusion postulated here is that law matters very fundamentally to childhood in modern African society, even if this might yet be in a way that differs from the modernized world. To an extent, the role of law remains aspirational; no one would argue that education has reached all qualifying children, or that early childhood marriage no longer occurs, or that children have been emancipated from their formerly subordinate position as non-actors in family or societal life.

But equally, the evidence is undeniable that there has been recognition of an evolving role for childhood in African society, a role that (as elsewhere) encompasses both a protectionist stance towards the very young, the marginalized, the orphaned and the vulnerable, as well as a version which acknowledges children's evolving autonomy and agency. In this reconstruction of the African child, it is asserted that law has played a crucial role.

In pre-colonial times, children were the exclusive responsibility of families and clans. The constitutional project which has been underway across Africa since the 1990s has seen children specifically identified as beneficiaries of rights to be accorded them by states. South Africa's signal constitutional provision has rendered children's claims justiciable across an array of fronts, and can be regarded as trendsetting. Further to constitutional reform, the ratification of international and domestic treaties has spurred a continent-wide revision of the status of children as seen in new children's statutes across the continent. These, too, see the state as critical to children's lives and the fulfillment of their rights. Additionally, the ongoing drive towards legislating for gender equality, required by treaty law, has benefitted children in relation to affiliation, equal parenting rights in marriage, enhancement of access to child support, and inheritance. ${ }^{57}$

The contents of the new children's laws are predominantly protectionist, yet contradictorily, to an extent more recognizing of autonomy (e.g. in HIV/Aids related/health matters) than are laws in the north. International and regional treaty definition of childhood itself, and there is widespread acceptance of childhood as the era that pertains until the attainment of the age of 18 .

Law defines and constitutes childhood. In modern Africa, this is no less true. Whereas it may be contended that the law on paper can be but weakly associated with cultural changes, it is suggested rather that where law is accompanied by ever-increasing access to education, the rapid expansion of means of communication, intensifying urbanization, and the investment of states in dedicated structures (e.g. Ministries), for the delivery of services to children, law can and does have a powerful effect in redefining custom and tradition.

\section{Notes}


2

Amanda Lloyd, 'Evolution of the African Charter on the Rights and Welfare of the Child and the African Committee of Experts: Raising the Gauntlet' (2002) 10 The International Journal of Children's Rights 183; Chuma Himonga, 'African Customary Law and Children's Rights: Intersections and Domains in a New Era' in Julia Sloth-Nielsen (ed), Children's Rights in Africa: A Legal Perspective (Ashgate, 2008) 73 .

3 Julia Sloth-Nielsen and Benyam Mezmur, 'A Dutiful Child: The Implications of article 31 of the African Children's Charter' (2008) 52 Journal of African Law 159.

4 Tom Bennett, 'Human Rights and the African Cultural tradition (1993) 22 Transformation 30.

5 K Mutua, 'The Banjul Charter and the African Cultural Fingerprint: An Evolution of the Language of Duties' (1995) 35 Virginia Journal of international Law 339. It is notable that African countries have expressed aversion to ratification of ILO Convention 132 relating to the Minimum Age of Admission to Employment, since child work is the norm and even an expected duty of maturation. See Jacqueline Gallinetti, 'An Assessment of the Significance of the Instrumental use of Children in the Commission of Offences as a Worst Form of Child Labour' (unpublished LLD thesis, University of the Western Cape, 2007) 207.

6 Annika Hipple, 'Coming of Age Rituals in Africa: Tradition and Change' (2008) IV Prudence International Magazine Journal available at <http://www.annikahipple.com/writing.samples> (accessed 28 June 2010); Manu Ampim, 'The Five Major African Initiation Rites' 2003 available at http://www.manuampim.com/AfricanInitiationRites.htm accessed 28 June 2010).

7 Lea Mwambene, 'The Impact of the Domestication of Rights in African Customary Family Laws: A Study of the Rights of Women in Malawi with some Reference to Developments in South Africa' (unpublished LLD thesis, University of the Western Cape, 2008).

8 IRIN, 'Africa-Asia: Youth in Crisis: Coming of Age in the 21st Century' June 2010, available at <http://www.irinnews.org $>$ (accessed 28 June 2010).

9 See Bart Rwezaura, 'Competing 'images' of childhood in the socio-legal systems of contemporary Sub Saharan Africa' (1998) 12 International Journal of Law, Policy and the Family 253 for a discussion of the notion of 'people-as-wealth' which emphasizes the communal value of intergenerational reproduction.

10 See Jacqueline Gallinetti, 'An Assessment of the Significance of the Instrumental Use of Children in the Commission of Offences as a Worst Form of Child Labour' op cit note 5 .

11 See Julia Sloth-Nielsen, 'The influence of international law on South Africa's juvenile justice reform process' (unpublished LLD thesis, University of the Western Cape, 2001) 334 et seq.

12 See Godfrey Odongo, 'The Domestication of International Law Standards on the Rights of the Child with Specific Reference to Juvenile Justice in the African Context' (unpublished LLD thesis, University of the Western Cape, 2005).

13 Committee on the Rights of the Child: Concluding observations to the Lesotho Country Report, CRC/C/15/Add.147 (26 January 2001). See, too Itumeleng Kimane 2006, The Lesotho Child Protection and Welfare Bill 2005: Why the delays in enacting the children's law?, Unpublished paper presented at the University of the Western Cape/Miller Du Toit conference, 'The globalization of child and family law', 26-27 January (2005).

14 Benyam Mezmur, 'From Angelina (to Madonna) to Zoe's ark: What are the "A-Z" Lessons for Intercountry Adoptions in Africa?' (2009) International Journal of Law, 
Policy and the Family 1; Benyam Mezmur, “"As painful as giving birth”: A reflection on the Madonna adoption saga' (2008) 41 Comparative and International Journal of Southern Africa 382; Julia Sloth-Nielsen, Belinda Van Heerden and Benyam Mezmur, 'Intercountry Adoption from a Southern and Eastern African perspective' (2010) International Family Law 86-97.

15 In Botswana, adoption legislation was introduced a year later, in 1952: Act Proc. 63 of 1952 (Chapter 28:01, Laws of Botswana).

16 For a historical trajectory of adoptions in traditional African societies, see Benyam Mezmur, 'Intercountry Adoption in an African Context: A Legal Perspective' (unpublished LLD thesis, University of the Western Cape, 2010) 30.

17 Julia Sloth-Nielsen and Jacqueline Gallinetti, Report on the review of child law in Mozambique (UNICEF and the Government of Mozambique, 2004).

18 Half hearted because many were set up with poor attention to infrastructural and maintenance costs. They remain sites for the abuse of children, rather than their rehabilitation or reintegration: see Julia Sloth-Nielsen and Benyam Mezmur. 'Surveying the research landscape to promote children's legal rights in an African context' (2007) 7 African Human Rights Law Journal 330-53.

${ }^{1} 9$ Noel Zaal, 'Court Services for the Child in Need of Alternative Care: a Critical Evaluation of Selected Aspects of the South African System' (unpublished LLD thesis, University of the Witwatersrand, 2008) chapter 2.

20 E.g. requiring children's identities to be protected in court procedures, or their cases to be separated from those of adults when alleged to be in conflict with the law. 21 Julia Sloth-Nielsen, 'Children's Rights in Africa' in Mashood Baderin (ed), 30 years of the African Human Rights System (University of Pennsylvania Press, forthcoming, 2011).

22 Julia Sloth-Nielsen, op cit note 11; Julia Sloth-Nielsen, "A short history of time: Charting the contribution of Social Development service delivery to enhance Child Justice 1996-2006' (2007) 43(4) Social Work/Maatskaplike Werk 317-29.

23 See, however, Julia Sloth-Nielsen and Benyam Mezmur, op cit note 18; Julia Sloth-Nielsen and Jacqueline Gallinetti, 'Just say sorry? Ubuntu, Africanisation and the child justice system in the Child Justice Act 75 of 2008' (paper presented at the conference on Ubuntu, Humanity and good faith/Equity as Flexible Principles in Law and Society in Southern Africa: Appropriate Principles in an Ever-changing world', Potchefstroom, 1-3 September 2010).

24 Ghana was the first country to ratify the CRC in 1990.

25 Nigel Cantwell, 'The Origins, Development and Significance of the United Nations Convention on the Rights of the Child' in Sharon Detrick, The United Nations Convention on the Rights of the Child: A guide to the travaux preparatoires (Kluwer, The Netherlands, 1992) 26.

26 Julia Sloth-Nielsen, 'Domestication of Children's Rights in National Legal Systems: Progress and Prospects' in Julia Sloth-Nielsen (ed), Children's Rights in Africa: A Legal Perspective (Ashgate, Dartmouth, 2008) 53.

27 UNICEF, Implementation handbook for the Convention on the Rights of the Child (2007) ix.

FGM of fairly recent origin can be traced (Egypt, Ethiopia) as also recent anti-trafficking enactments (Benin, Mozambique, South Africa).

28 This has now been proscribed in the 2005 Constitution of Burundi.

29 A host of laws proscribing FGM of fairly recent origin can be traced (Egypt, Ethiopia) as also recent anti-trafficking enactments (Benin, Mozambique, South Africa). 
30 The author attended a workshop on proposed amendments to the Kenya Children's Act in Naivasha, May 2010, and a copy of the proposed draft Ugandan amendments are on file.

31 Danwood Chirwa, 'The Merits and Demerits of the African Charter on the Rights and Welfare of the Child' (2002) 10 International Journal on Children's Rights 157; Dejo Olowu, 'Protecting children's rights in Africa: A critique of the African Charter on the Rights and Welfare of the Child' (2002) International Journal on Children's Rights 137; Frans Viljoen, 'The African Charter on the Rights and Welfare of the Child' in Trynie Boezart T (ed), Child Law in South Africa (Juta, Cape Town, 2010) 331; Benyam Mezmur, 'The African Charter v The UN Convention on the Rights of the Child: A Zero Sum Game?' (2008) 23 SA Public Law 1; Julia Sloth-Nielsen, op cit note 21.

32 Only Egypt, Morocco, Algeria and Senegal were actively involved in the drafting process of the CRC.

33 Julia Sloth-Nielsen, op cit note 21.

34 Julia Sloth-Nielsen and Benyam Mezmur, op cit note 3.

35 Julia Sloth-Nielsen, op cit note 26.

36 The National Agency for the Prohibition of Trafficking in Persons (NAPTIP) of Nigeria commenced investigations on the matter with a view to taking relevant action while the Supreme Council for Sharia in Nigeria has challenged the Federal Government and the National Assembly of Nigeria in court.

37 In Geldenhuys $v$ The State 2008 ZASCA 47, the differential ages of consent to sexual intercourse for males and females ( 16 for girls and 18 for boys) was found to be unconstitutional, but with retrospective effect as the amended Criminal Law (Sexual Offences) Amendment Act 32 of 2007 had already equalized the minimum age via legislative reform.

38 A constitutional challenge to the law is pending but at the time of writing had not been heard.

39 The South African Children's Act 38 of 2005 (section 130) permits independent consent to HIV testing from the age of 12 or even below this age if the child is of an age and maturity to understand the implications of the test.

40 Children's Status Act 6 of 2006, in force since 3 November 2008.

41 Julia Sloth-Nielsen, Nkatha Murungi and Lorenzo Wakefield, 'Does the differential criterion for vesting parental rights and responsibilities of unmarried parents violate international law? A legislative and social study of three African countries' (2011) 55(2) Journal of African Law 203.

42 When the Act came into force on 1 July 2007, qualifying fathers acquired parental responsibilities and rights in respect of their biological children retrospectively.

43 Nigeria reported to the African Committee of Experts in November 2008 that the creation of 34 children's parliaments in 19 states was the vehicle for giving effect to hearing children's views, and that many children's clubs had been set up at state level. The ordinance of Burkina Faso establishing children's parliaments dates from 1998.

44 Cheryl Frank and Louise Ehlers, 'Child participation in Africa' in Julia Sloth-Nielsen (ed), Children's Rights in African Context; A Legal Perspective (Ashgate, 2008).

45 African Child Policy Forum, 'Harmonizsation of Child Law in Central and West Africa' (forthcoming, copy on file with the author).

46 Cheryl Frank and Louise Ehlers, op cit note 44.

47 Public Participation in Law Reform: Revision of Namibia's Draft Child Care and Protection Bill (Final Report, 2010) Legal Assistance Centre and UNICEF, Windhoek, 2010. 
48 Arlene Skolnick, 'The Limits of Childhood: Conceptions of Child Development and Social Context' 39(3) Law and Contemporary Problems Children and the Law (Summer, 1975).

49 Kristen Cheney, "Village Life Is Better Than Town Life": Identity, Migration, and Development in the Lives of Ugandan Child Citizens' (2004) 47(3) African Studies Review,.

50 See Benyam Mezmur and Julia Sloth-Nielsen, 'The right to education in Africa: Taking stock' in C. J. Davel (ed), Essays in honour of Hans Visser (Juta and Co, 2008).

51 Prinslean Mahery et al, A guide to the Children's Act for health professionals (4th ed, 2010), Children's Institute, University of Cape Town, quoting the Department of Health HIV Counselling and testing (HCT) Policy Guidelines of March 2010 at 15..

52 There was much adverse press coverage when this provision was put into operation on 1 July 2007.

53 There is currently a national debate about a recent plan of the National Department of Health to conduct HIV testing in all secondary schools.

54 Julia Sloth-Nielsen and Benyam Mezmur, 'Confronting Hydra Head On: Children's rights in the era of HIV/Aids' in Julia Sloth-Nielsen (ed), Children's Rights in Africa: A Legal Perspective (Ashgate, 2008).

55 See, e.g. Niger (Law $\mathrm{n}^{\circ} 2003-25$ of the 13 June 2003 on female genital mutilation).

56 Egypt enacted criminal sanctions for FGM which came into effect from June 2008. See, Julia Sloth-Nielsen and Benyam Mezmur, 'Out of the starting blocks: the 12th and 13th meeting of the African Committee of Experts on the Rights and Welfare of the Child' (2009) 9 African Human Rights Law Journal 336.

57 An example is the Bhe case (Bhe and others $v$ Magistrate Khayeltisha and others (Commission for Gender Equality as Amicus Curiaie; Shibi and Sithole and Others; South African Human Rights Commission and Another $v$ President of the Republic of South Africa and others) 2005 (1) SA 580 (CC), in which the rule of male primogeniture was held to discriminate unfairly and unconstitutionally against girl children on the grounds of sex and birth, as it prevented them from inheriting from their deceased father. 